\title{
Expression analyses of human cleft palate tissue suggest a role for osteopontin and immune related factors in palatal development
}

\author{
Linda P. Jakobsen ${ }^{1,2,9}$, Rehannah Borup ${ }^{3}$, \\ Janni Vestergaard ${ }^{1}$, Lars A. Larsen', \\ Kasper Lage ${ }^{4}$, Lisa Leth Maroun ${ }^{5}$, \\ Inger Kjaer ${ }^{6}$, Carsten U. Niemann ${ }^{7}$, \\ Mikael Andersen ${ }^{2}$, Mary A. Knudsen ${ }^{2}$, \\ Kjeld Møllgård ${ }^{8}$ and Niels Tommerup ${ }^{1}$ \\ ${ }^{1}$ Wilhelm Johannsen Centre for Functional Genome Research \\ Department of Cellular and Molecular Medicine, Panum Institute \\ Copenhagen, Denmark \\ ${ }^{2}$ Department of Plastic- and Reconstructive Surgery and Burns Unit \\ ${ }^{3}$ Department of Clinical Biochemistry \\ University Hospital of Copenhagen \\ Rigshospitalet, Denmark \\ ${ }^{4}$ Center for Biological Sequence Analysis (CBS) \\ BioCentrum-DTU \\ Technical University of Denmark \\ ${ }^{5}$ Department of Pathology \\ University Hospital of Copenhagen \\ Rigshospitalet, Denmark \\ ${ }^{6}$ Department of Orthodontics \\ Panum Institute \\ Copenhagen, Denmark \\ ${ }^{7}$ Department of Haematology, Granulocytlaboratoriet \\ University Hospital of Copenhagen \\ Rigshospitalet, Denmark \\ ${ }^{8}$ Department of Medical Anatomy \\ Panum Institute \\ Copenhagen, Denmark \\ ${ }^{9}$ Corresponding author: Tel, 45 35327836; \\ Fax, 45 35327845; E-mail, lindapjakobsen@ gmail.com \\ DOI 10.3858/emm.2009.41.2.010
}

Accepted 16 October 2008

Abbreviations: CL, isolated cleft lip; CL/P, cleft lip and/or palate; CLP, combined cleft lip and palate; COGENE, Craniofacial and Oral Gene Expression Network; CP, isolated cleft palate; QPCR, quantitative RT-PCR

\begin{abstract}
Cleft lip and/or palate (CL/P) is a common congenital malformation with a complex etiology which is not fully elucidated yet. Epidemiological studies point to differ-
\end{abstract}

ent etiologies in the cleft lip and palate subgroups, isolated cleft lip (CL), isolated cleft palate (CP) and combined cleft lip and palate (CLP). In order to understand the biological basis in these cleft lip and palate subgroups better we studied the expression profiles in human tissue from patients with $\mathrm{CL} / \mathrm{P}$. In each of the $\mathrm{CL} / \mathrm{P}$ subgroups, samples were obtained from three patients and gene expression analysis was performed. Moreover, selected differentially expressed genes were analyzed by quantitative RT-PCR, and by immunohistochemical staining of craniofacial tissue from human embryos. Osteopontin (SPP1) and other immune related genes were significantly higher expressed in palate tissue from patients with CLP compared to CP and immunostaining in palatal shelves against SPP1, chemokine receptor 4 (CXCR4) and serglycin (PRG1) in human embryonic craniofacial tissue were positive, supporting a role for these genes in palatal development. However, gene expression profiles are subject to variations during growth and therefore we recommend that future gene expression in CL/P studies should use tissue from the correct embryonic time and place if possible, to overcome the biases in the presented study.

Keywords: cleft lip and palate; congenital abnormalities; gene expression profiling; osteopontin; serglycin

\section{Introduction}

Cleft lip and/or palate (CL/P) is a common congenital malformation affecting approximately 2 per 1000 newborns worldwide (Murray, 2002) and causing a major psychosocial and economic burden for the families. Gaining insight into the etiology of CL/P is important as it may lead to improved diagnosis, counselling and perhaps preventive measures in the future. Although CL/P is a complex disease caused by both environmental and genetic factors, most studies point to genetic factors as the major determinants (Christensen and Mitchell, 1996). Recently, several genes implicated in CL/P have been identified (Jugessur and Murray, 2005), but they can only account for a fraction of the etiology.

Moreover, epidemiological studies point to that $\mathrm{CL} / \mathrm{P}$ subgroups may have different etiologies, as 
isolated cleft palate (CP) and combined cleft lip and palate (CLP) seldom occur in the same families (Fogh-Andersen, 1942), and isolated cleft lip $(C L)$ and CLP display different sex ratios and prevalences of associated malformations (Harville et al., 2005).

To gain more insight into the genetic etiology of CL/P we studied expression profiles in lip and palate tissue from patients with different types of orofacial cleft: CL, CP and CLP, rationalizing that the epidemiological differences may reflect differences in the underlying molecular processes.

\section{Results}

\section{Affymetrix GeneChip analysis}

We identified 11 genes which were differentially

Table 1. Differently expressed genes $(P<.05)$ on Affymetrix GeneChip in palate tissue from patients with cleft palate only (CP) versus palate tissue from patients with cleft lip and palate (CLP), selected genes validated by QPCR.

\begin{tabular}{|c|c|c|c|c|c|c|}
\hline Gene & $\begin{array}{l}\text { Accession } \\
\text { number }\end{array}$ & $\begin{array}{l}\text { Chromosomal } \\
\text { locus }\end{array}$ & $\begin{array}{l}\text { Biological } \\
\text { functions }\end{array}$ & $\begin{array}{c}\text { Affy fold } \\
\text { change } \\
\text { (CLP vs. CP) }\end{array}$ & $\begin{array}{l}\text { QPCR } \\
\text { fold } \\
\text { change }\end{array}$ & $\begin{array}{l}\text { COGENE } \\
\text { Affy/ } \\
\text { SAGE }\end{array}$ \\
\hline CD14 antigen & NM_000591 & $5 q 31.3$ & $\begin{array}{l}\text { Phagocytosis, apoptosis, } \\
\text { cell surface receptor linked } \\
\text { signal transduction }\end{array}$ & 2.14 & & $A / P$ \\
\hline Serglycin (PRG1) & $\begin{array}{l}\text { J03223, } \\
\text { NM_002727 }\end{array}$ & $10 q 21.3$ & - & $\begin{array}{r}2.12- \\
2.48\end{array}$ & & N.A./A \\
\hline $\begin{array}{l}\text { Immunoglobulin } \\
\text { lambda constant } 2\end{array}$ & $\begin{array}{l}\text { M87790, } \\
\text { AA680302, } \\
\text { AV698647 }\end{array}$ & $22 q 11.22$ & $\begin{array}{l}\text { Immune response, } \\
\text { antigen binding }\end{array}$ & $\begin{array}{r}18.90- \\
19.62\end{array}$ & & $\mathrm{P} / \mathrm{P}$ \\
\hline $\begin{array}{l}\text { Osteopontin/secreted } \\
\text { phosphoprotein } 1 \\
\text { (SPP1) }\end{array}$ & M83248 & $4 q 22.1$ & $\begin{array}{l}\text { Ossification, anti-apoptosis, } \\
\text { inflammatory response, } \\
\text { cell adhesion and signalling, } \\
\text { leukocyte chemotaxis, T-helper } \\
1 \text { type immune response }\end{array}$ & 4.46 & $\begin{array}{l}5.3 \\
(P<.05)\end{array}$ & $\mathrm{P} / \mathrm{P}$ \\
\hline $\begin{array}{l}\text { Chemokine receptor } 4 \\
\text { (CXCR4) }\end{array}$ & $\begin{array}{l}\text { AF348491, } \\
\text { AJ224869 }\end{array}$ & $2 q 21.3$ & $\begin{array}{l}\text { Lymphocyte migration, } \\
\text { nonmuscle myosin binding, } \\
\text { co-receptor for T-cell line- } \\
\text { adapted human immuno- } \\
\text { deficiency virus type } 1\end{array}$ & $\begin{array}{l}1.92- \\
2.93\end{array}$ & $\begin{array}{l}2.0 \\
(P<.05)\end{array}$ & $A / P$ \\
\hline $\begin{array}{l}\text { Adenosine } \\
\text { monophosphate } \\
\text { deaminase } 2 \\
\text { (isoform L) } \\
\text { (AMPD2) }\end{array}$ & Al916249 & $1 \mathrm{p} 13.3$ & $\begin{array}{l}\text { Purine nucleotide } \\
\text { metabolism, AMP } \\
\text { deaminase activity }\end{array}$ & 1.67 & $\begin{array}{l}1.9 \\
(P<.05)\end{array}$ & $\mathrm{A} / \mathrm{P}$ \\
\hline $\begin{array}{l}\text { Regeneration } \\
\text { associated muscle } \\
\text { protease }\end{array}$ & Al671186 & $11 \mathrm{p} 13$ & 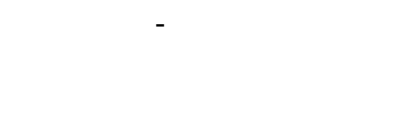 & -2.07 & & N.A./A \\
\hline $\begin{array}{l}\text { Hypothetical protein } \\
\text { MGC27165 and } \\
\text { gb:AJ239383 }\end{array}$ & $\begin{array}{l}\text { S55735/ } \\
\text { AJ239383 }\end{array}$ & $14 q 32.33$ & $\begin{array}{l}\text { Immune response, antigen } \\
\text { binding (function from IGHG1 } \\
\text { and IGHA1) }\end{array}$ & $\begin{array}{l}4.67- \\
11.19\end{array}$ & & N.A./P \\
\hline $\begin{array}{l}\text { Immunoglobulin } \\
\text { kappa constant }\end{array}$ & $\begin{array}{l}\text { AW575927, } \\
\text { BC005332, } \\
\text { BG485135, } \\
\text { M63438 }\end{array}$ & $2 p 11.2$ & $\begin{array}{l}\text { Immune response, } \\
\text { antigen binding }\end{array}$ & $\begin{array}{l}9.46- \\
11.05\end{array}$ & & N.A./P \\
\hline $\begin{array}{l}\text { Likely ortholog of rat } \\
\text { vacuole membrane } \\
\text { protein } 1\end{array}$ & BF674052 & $17 q 23.1$ & - & 2.65 & & N.A./P \\
\hline $\begin{array}{l}\text { Hypothetical protein } \\
\text { LOC124773 }\end{array}$ & Al190160 & $17 q 23.2$ & - & 6.13 & & N.A./A \\
\hline
\end{tabular}

Accessions numbers are from the Affymetrix GeneChip analysis.

Functions are from the functions of the human proteins listed in Gene Ontology (GO), http://www.geneontology.org/.

The COGENE database was searched for expression in the relevant tissues (see Methods section) in Affymetrix chip analyses and SAGE libraries, A, absent; P, present; N.A., not available. A SAGE tag had to be identified twice or more to be considered present. 
expressed in the palate tissue from CP and CLP respectively: CD14 antigen, Serglycin (PRG1), Immunoglobulin lambda constant 2, Osteopontin/ secreted phosphoprotein 1 (SPP1), Chemokine receptor 4 (CXCR4), Adenosine monophosphate deaminase 2 (isoform L) (AMPD2), Regeneration associated muscle protease, Hypothetical protein MGC27165, Immunoglobulin kappa constant, Likely ortholog of rat vacuole membrane protein 1, Hypothetical protein LOC124773 (Table 1).

We identified 19 genes differentially expressed in the lip tissue from CL and CLP respectively: Bone marrow stromal cell antigen 2 (BST2), SMART/ HDAC1 associated repressor protein (SPEN), Deiodinase, iodothyronine type II (DIO2), Cytochrome c oxidase subunit VIla polypeptide 1 (COX7A1), Butyrophilin, subfamily 3 , member A3 (BTN3A3), Crystallin, alpha B (CRYAB), gb:M27487, gb:AA770596, Major histocompatibility complex, class II, DQ alpha 2 (HLA-DQA1), Heat shock protein, alpha-crystallin-related, B6 (HSPB6), Protein kinase $\mathrm{C}$ and casein kinase substrate in neurons 3 (PACN3), EGF-like-domain, multiple 6 (EGFL6), Calsequestrin 1 (CASQ1), gb:AF116709, Nuclear factor I/X (CCAAT-binding transcription factor) (NFIX), Kinase interacting stathmin (UHMK1), Hypothetical protein (CMYA1), Hypothetical protein MGC34032, EH domain binding protein 1-like 1 (EHBP1L1) (Table 2).

\section{QPCR}

While the GeneChip results from the palate tissue were verified by QPCR (Table 1), the results from the lip tissue could not be verified as it only showed a non-significant trend (Table 2), and therefore we focus on the results from the palate tissue in the following discussion.

\section{Immunohistochemistry}

One important bias in our study is that the tissue samples investigated are not from the foetal period where the development of the lip and palate takes place but from fully developed children aged 4-16 months. To investigate if the genes identified in the GeneChip analysis were also expressed during human development, we performed immunohistochemical staining in craniofacial tissue from human embryos (6th to 11th week of gestation). Immunostainings against the selected proteins osteopontin (SPP1), chemokine receptor 4 (CXCR4) and serglycin (PRG1) in frontal sections showed a characteristic, and in many respects complementary expression during initial growth and elevation of the palatal shelves (corresponding to 6-8 gestational weeks, Figure $1 A$ and $B$ ), and during fusion of the palatal processes and removal of the medial edge epithelium at the site of fusion (corresponding to 9-11 gestational weeks, Figure 1C and D). $P R G 1$ protein expression was only present during the palatal fusion and medial edge epithelium breakdown (Figure 1E). Together, this indicates that all the three chosen genes were present in the human palate during fusion and therefore may play a role in normal palate development.

Table 2. Differently expressed genes $(P<.05)$ on Affymetrix GeneChip in lip tissue, from patients with cleft lip only (CL) versus lip tissue from patients with cleft lip and palate (CLP), selected genes validated by QPCR (ns is non-significant).

\begin{tabular}{|c|c|c|c|c|c|c|}
\hline Gene & $\begin{array}{l}\text { Accession } \\
\text { number }\end{array}$ & $\begin{array}{l}\text { Chromosomal } \\
\text { locus }\end{array}$ & $\begin{array}{l}\text { Biological } \\
\text { functions }\end{array}$ & $\begin{array}{c}\text { Affy fold } \\
\text { change } \\
\text { (CLP vs. CL) }\end{array}$ & $\begin{array}{l}\text { QPCR } \\
\text { fold } \\
\text { change }\end{array}$ & $\begin{array}{l}\text { COGENE } \\
\text { Affyl } \\
\text { SAGE }\end{array}$ \\
\hline $\begin{array}{l}\text { Bone marrow stromal } \\
\text { cell antigen } 2 \text { (BST2) }\end{array}$ & NM_004335 & 19p13.11 & $\begin{array}{l}\text { Humoral immune response, } \\
\text { cell proliferation and } \\
\text { signalling, development }\end{array}$ & -2.11 & $-2.1, \mathrm{~ns}$ & A/P \\
\hline $\begin{array}{l}\text { SMART/ HDAC1 ass. } \\
\text { repressor protein } \\
\text { (SPEN) }\end{array}$ & AL524033 & $1 p 36.13$ & - & -1.90 & $-1.2, \mathrm{~ns}$ & N.A./P \\
\hline $\begin{array}{l}\text { Deiodinase, } \\
\text { iodothyronine } \\
\text { type II }(D / O 2)\end{array}$ & U53506 & $14 q 31.1$ & $\begin{array}{l}\text { Thyroid hormone } \\
\text { generation, } \\
\text { selenium binding }\end{array}$ & -2.49 & $-1.6, \mathrm{~ns}$ & A/P \\
\hline $\begin{array}{l}\text { Cytochrome c oxidase } \\
\text { subunit VIla polypeptide } \\
1(C O X 7 A 1)\end{array}$ & NM_001864 & $19 q 13.12$ & $\begin{array}{l}\text { Cytochrome-c } \\
\text { oxidase activity }\end{array}$ & -2.02 & & N.A./A \\
\hline $\begin{array}{l}\text { Butyrophilin, subfamily } \\
3 \text {, member A3 } \\
\text { (BTN3A3) }\end{array}$ & NM_006994 & $6 \mathrm{p} 22.1$ & - & -1.70 & & A/A \\
\hline
\end{tabular}


Table 2. Continued.

\begin{tabular}{|c|c|c|c|c|c|c|}
\hline Gene & $\begin{array}{l}\text { Accession } \\
\text { number }\end{array}$ & $\begin{array}{l}\text { Chromosomal } \\
\text { locus }\end{array}$ & $\begin{array}{l}\text { Biological } \\
\text { functions }\end{array}$ & $\begin{array}{l}\text { Affy fold } \\
\text { change } \\
\text { (CLP vs. CL) }\end{array}$ & $\begin{array}{l}\text { QPCR } \\
\text { fold } \\
\text { change }\end{array}$ & $\begin{array}{l}\text { COGENE } \\
\text { Affy/ } \\
\text { SAGE }\end{array}$ \\
\hline $\begin{array}{l}\text { Crystallin, alpha B } \\
\text { (CRYAB) }\end{array}$ & AF007162 & $11 q 23.1$ & $\begin{array}{l}\text { Protein folding, muscle } \\
\text { contraction, visual perception }\end{array}$ & -2.10 & $-2.0, \mathrm{~ns}$ & N.A./A \\
\hline gb:M27487 & $\begin{array}{l}\text { M27487 } \\
\text { (Aligns to } \\
\text { HLA-DPA1) }\end{array}$ & $\begin{array}{l}\text { 6p21.32 } \\
\text { and 6p25.1 }\end{array}$ & $\begin{array}{l}\text { Immune response, integral to } \\
\text { plasma membrane } \\
\text { (function from HLA-DPA1) }\end{array}$ & -2.13 & & N.A./A \\
\hline gb:AA770596 & $\begin{array}{l}\text { AA770596 } \\
\text { (aligns to part } \\
\text { of MARCKS) }\end{array}$ & $6 q 22.1$ & $\begin{array}{l}\text { Cell motility, actin filament } \\
\text { binding (function from } \\
\text { MARCKS) }\end{array}$ & -2.06 & & $\begin{array}{r}\text { N.A./P (MARCKS } \\
\text { present in SAGE) }\end{array}$ \\
\hline $\begin{array}{l}\text { Major histocompatibility } \\
\text { complex, class II, } \\
\text { DQ alpha } 2 \\
\text { (HLA-DQA1) }\end{array}$ & X00452 & $6 p 21.32$ & - & -3.71 & & N.A./P \\
\hline $\begin{array}{l}\text { Heat shock protein, } \\
\text { alpha-crystallin-related, } \\
\text { B6 (HSPB6) }\end{array}$ & AL551046 & $19 q 13.12$ & Protein binding & -2.81 & & N.A./A \\
\hline $\begin{array}{l}\text { Protein kinase } \mathrm{C} \text { and } \\
\text { casein kinase substrate } \\
\text { in neurons } 3(P A C N 3)\end{array}$ & NM_016223 & 11p11.2 & $\begin{array}{l}\text { Negative regulation of } \\
\text { endocytosis, cytoskeletal } \\
\text { protein binding }\end{array}$ & -1.75 & $1.0, \mathrm{~ns}$ & $\begin{array}{l}\text { N.A./P } \\
\text { (SAGE: 4th } \\
\text { week posterior } \\
\text { rhombomeres) }\end{array}$ \\
\hline $\begin{array}{l}\text { EGF-like-domain, } \\
\text { multiple } 6 \text { (EGFL6) }\end{array}$ & NM_015507 & Xp22.2 & - & -2.65 & $-1.6, n s$ & N.A./P \\
\hline $\begin{array}{l}\text { Calsequestrin } 1 \\
\text { (CASQ1) }\end{array}$ & NM_001231 & $1 q 23.2$ & $\cos 2 \cos 20$ & -3.02 & & N.A./A \\
\hline gb:AF116709 & $\begin{array}{l}\text { AF116709 } \\
\text { (Aligns to H19 } \\
\text { and JMJD2C) }\end{array}$ & $\begin{array}{l}11 \mathrm{p} 15.5 \\
\text { and 9p24.1 }\end{array}$ & $\begin{array}{l}\text { H19 (imprinted maternally } \\
\text { expressed untranslated } \\
\text { mRNA) and JMJD2C } \\
\text { (jumonji domain containing } 2 \mathrm{C} \text { ) }\end{array}$ & ) & & $\begin{array}{l}\text { N.A./P }(H 19 \\
\text { present in } \\
\text { SAGE) }\end{array}$ \\
\hline $\begin{array}{l}\text { Nuclear factor I/X } \\
\text { (CCAAT-binding } \\
\text { transcription factor) } \\
(\text { NFIX) }\end{array}$ & Al817698 & 19p13.13 & Regulation of transcription & -2.14 & & A/A \\
\hline $\begin{array}{l}\text { Kinase interacting } \\
\text { stathmin (UHMK1) }\end{array}$ & Al249980 & $1 q 23.3$ & $\begin{array}{l}\text { Amino acid phosphorylation, } \\
\text { cell cycle arrest, regulation of } \\
\text { protein export from nucleus }\end{array}$ & -1.91 & & N.A./P \\
\hline $\begin{array}{l}\text { Hypothetical protein } \\
\text { (CMYA1) }\end{array}$ & AW755250 & 3p22.2 & - & -2.57 & & N.A./A \\
\hline $\begin{array}{l}\text { Hypothetical protein } \\
\text { MGC34032 }\end{array}$ & $\begin{array}{l}\text { AA001450, } \\
\text { AW020413 }\end{array}$ & $1 p 31.1$ & - & $\begin{array}{r}2.00- \\
5.08\end{array}$ & & N.A./P \\
\hline $\begin{array}{l}\text { EH domain binding } \\
\text { protein 1-like } 1 \\
\text { (EHBP1L1) }\end{array}$ & AK092750 & $11 q 13.1$ & - & -2.08 & & N.A./A \\
\hline
\end{tabular}

Accessions numbers are from the Affymetrix GeneChip analysis.

Functions are from the functions of the human proteins listed in Gene Ontology (GO), http://www.geneontology.org/.

The COGENE database was searched for expression in the relevant tissues (see Methods section) in Affymetrix chip analyses and SAGE libraries, A, absent; P, present; N.A., not available. A SAGE tag had to be identified twice or more to be considered present.

\section{In silico analysis}

CD14, SPP1, CXCR4, AMPD2 and the immunoglobulin kappa and lambda constants found in the palate tissue were also identified in COGENEs Affymetrix and/or SAGE profiles, and our human protein interaction network identified a putative interaction between SPP1 and PRG1.
The palate tissue from the two CL/P subgroups $\mathrm{CP}$ and CLP are also from two different age groups (16 and 4 months, respectively). This may introduce a bias to our study, as the differences in gene expression may be related to either differences in age, CL/P type or both. To circumvent this problem, we studied the expression of spp1 by QPCR 


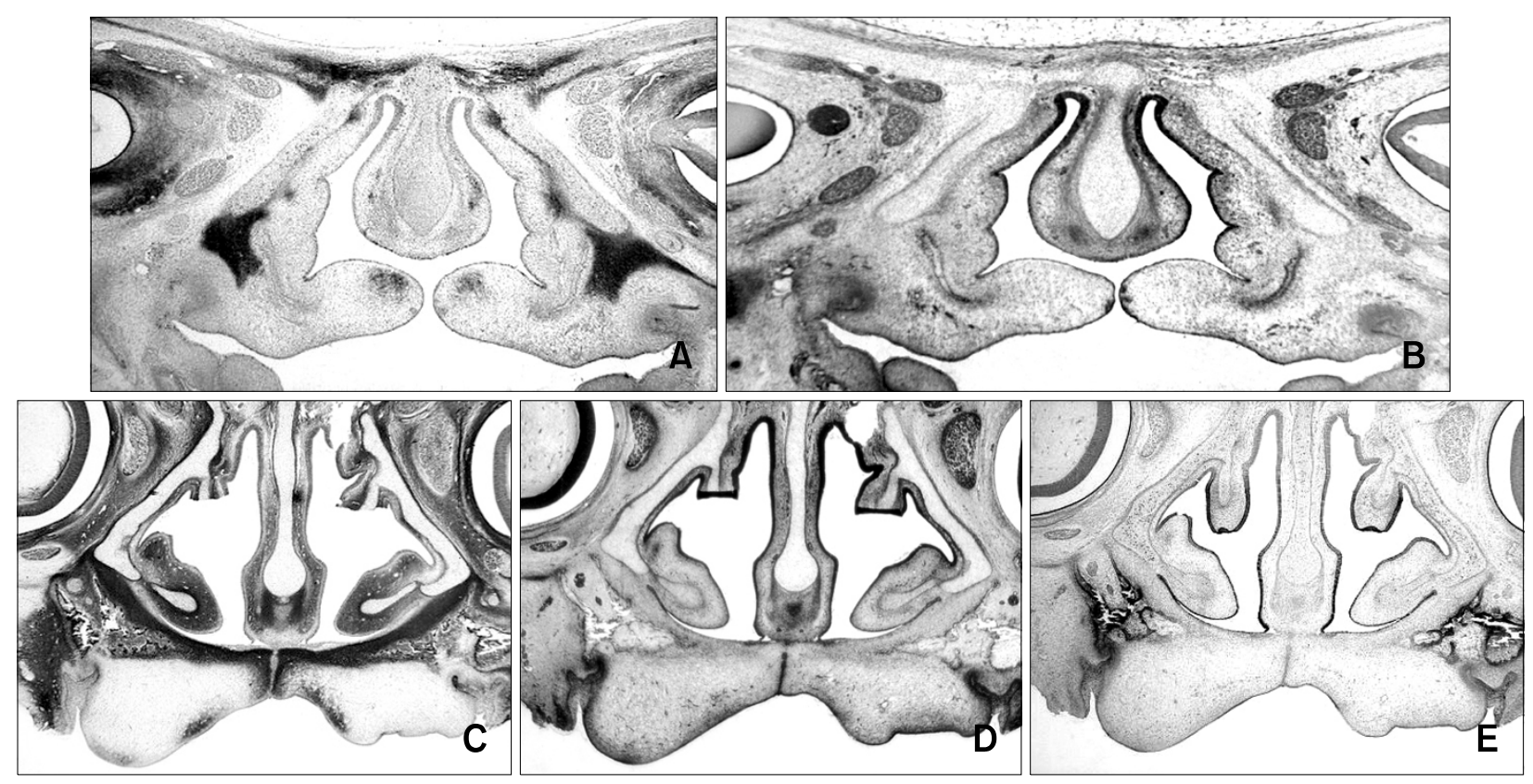

Figure 1. Immunohistochemical staining of human embryonic craniofacial sections. (A) During elevation (6th-8th week embryos) of the palatal shelves osteopontin (SPP1) protein is present in the palatal mesenchyme. (B) Chemokine receptor 4 (CXCR4) was present in the epithelial lining of the oronasal cavity and the palatal shelves. (C) During fusion (9th-11th week fetuses) of the palatal shelves SPP1 is present in the palatal mesenchyme and (D) CXCR4 is present in the epithelium of the oronasal cavity, including the medial edge epithelium, where the palatal shelves meet and fuse. (E) Serglycin (PRG1) protein expression was not present in the early gestational age (6-8 weeks), but became apparent during palatal fusion in the epithelial lining of the oronasal cavity and in the medial edge epithelium. Black color indicates expression. (Hematoxylin-eosin or toluidine blue staining, primary magnification $\times 1.25$ ).

in wild type mouse palates (three palate samples from each of the four age groups; newborn, 1 week, 1 month and 2 months old, for information on cDNA synthesis and primer sequences, see Methods), and found an increase in spp1 expression in 1 week old mouse palates compared to the other age groups (results not shown).

\section{Discussion}

Expression analysis in human lip and palate tissue from patients with different types of cleft lip and palate has not been performed before, and epidemiological studies suggest different etiologies in the three CL/P subgroups; CL, CLP and CP (FoghAndersen, 1942; Harville et al., 2005). Hence, we performed the present study in order to obtain more information on the genetic etiology of CL/P in general and more information on the genetic differences in the CL/P subgroups.

Ideally, we would have preferred to compare expression profiles from patients with CL/P with samples from normal children at comparable ages, but this was unfortunately not available to us. Thus, it is not possible from the present study to determine which cleft types have up- or downre- gulated gene expression patterns compared to normal children, merely expression differences were detected.

Our GeneChip analysis identified 11 genes differentially expressed in palate tissue from $\mathrm{CP}$ and CLP (CD14 antigen, $P R G 1$, Immunoglobulin lambda constant 2, SPP1, CXCR4, AMPD2, Regeneration associated muscle protease, Hypothetical protein MGC27165, Immunoglobulin kappa constant, Likely ortholog of rat vacuole membrane protein 1 , Hypothetical protein LOC124773) (Table 1) and 19 genes differentially expressed in the lip tissue from $\mathrm{CL}$ and CLP (BST2, SPEN, DIO2, COX7A1, BTN3A3, CRYAB, gb:M27487, gb:AA770596, HLADQA1, HSPB6, PACN3, EGFL6, CASQ1, gb:AF116709, NFIX, UHMK1, CMYA1, Hypothetical protein MGC34032, EHBP1L1) (Table 2).

In the palate tissue all genes, except Regeneration associated muscle protease, were higher expressed in patients with CLP than CP and in the lip tissue all genes, except Hypothetical protein MGC34032, were higher expressed in patients with $C L$ than CLP. The reason for these skewed results is unclear, but a possible explanation may be that the genes or some of them are working in a mutual biological pathway.

While QPCR validated the GeneChip results in 
palate tissue, QPCR gene expression analysis of lip tissue only showed non-significant changes. This may indicate that the differences in the molecular processes underlying CL and CLP are small or at least undetectable by the techniques used in our study. Consequently, the following discussion will focus on the genes identified as differentially expressed in the palate tissue in the two CL/P subgroups CLP and CP.

Secreted phosphoprotein 1 , also referred to as osteopontin (SPP1) was expressed at significantly higher levels in the palate tissue from the CLP patients compared to the CP patients with GeneChip analysis and QPCR, and it was also identified in human embryonic palate by immunohistochemistry. Although spp1 transgenic mice do not display CL/P (Rittling et al., 1998), SPP1 appears to be a promising candidate as SPP1 is involved in ossification (Jono et al., 2000), and hence potentially involved in the formation of bone in the palate. Moreover, SPP1 has been emphasized as important for palate formation in two recent micro array studies on foetal murine palates, which demonstrated significant changes in expression of SPP1 during craniofacial development (Brown et al., 2003; Mukhopadhyay et al., 2004).

Our protein interaction network identified a putative interaction between SPP1 and Serglycin (PRG1) (Rual et al., 2005), another gene differentially expressed in palate tissue. PRG1 was also identified in immunostainings of human embryonic palate. Our demonstration of PRG1 and the recent finding that $P R G 1$ plays a role in the ossification process by inhibiting bone mineralization in vitro (Theocharis et al., 2006), implicates PRG1 as a candidate gene for the regulation of normal palatal development.

Interestingly, several genes with a function in the immune system were differentially expressed in palate tissue from CLP and CP: CD14 antigen, CXCR4, and immunoglobulin kappa and lambda constants were all expressed at significantly higher levels in palate tissue from CLP patients compared to CP (see Table 1 for further information on biological functions of the proteins). Immunostainings showed that CXCR4 was present in the medial edge epithelium in sections of human embryonic palate, supporting a role for CXCR4 in normal palate development.

The involvement of the immune system in relation to $C L / P$ is presently unknown, but animal studies support a role for immune related factors in craniofacial development: Immune stimulation following teratogenic exposure in pregnant mice decreased the frequency of foetal abnormalities, including cleft palate (Holladay et al., 2002). This observed "rescue" of foetal abnormalities was considered mediated by TGF $\beta 3, I G F S$ and ILs (Sharova et al., 2002). TGF 33 is a known immunomodulatory cytokine (Wahl et al., 2004) and is considered a CL/P candidate gene based on association- and linkage studies and mouse models (Murray, 2002). Moreover, previously recognized CL/P genes have functions related to the immune response, most notably, interferon regulating factor 6 (IRF6) (Taniguchi and Takaoka, 2002; Zucchero et al., 2004) and poliovirus receptor-like 1 (PVRL1) (Suzuki et al., 2000; Avila et al., 2006).

The reason why TGF $\beta 3$, IRF6 and PVRL 1 were not detected in the present study may be that we identified differences in expression in the CL/P subgroups, so if TGF $\beta 3$, IRF6 and PVRL1 have similar expression profiles in both CP and CLP, we would not identify it.

Furthermore, an epidemiological study has pointed to an association between maternal infection during pregnancy and increased incidence of CL/P (Metneki et al., 2005), and together these studies suggest a link between the immune system and craniofacial development.

A cross regulation between bone metabolism and the immune system has been identified (Walsh et al., 2006), and our findings are suggestive of an interaction between the immune response and bone metabolism in palate formation, as SPP1 and $P R G 1$ are involved in both processes (Jono et al., 2000; Theocharis et al., 2006; Kolset and Tveit, 2008).

A potential weakness of this study is that the expression profiles in the tissue collected and analyzed postnatally may not reflect embryonic expression, as the cleft-causing processes may have ended by the time of analysis. We tried to circumvent this problem by performing immunostainings in human embryonic craniofacial tissue sections, and detected all the selected proteins (SPP1, PRG1 and CXCR4), which support a role for these genes in at least normal palate formation. However, this does not necessarily indicate that these genes play a different role in CP compared to CLP, as the palate tissue samples from the CP and CLP patients were from different age groups (approximately 16 months and 4 months of age, respectively), because of differences in the surgical protocols.

In order to address this age-related problem, we studied the expression of spp1 by QPCR in wild type mouse palates and found a surge in spp1 expression in 1 week old mouse palates compared to newborn mouse, 1 month and 2 months old mouse palates. As CLP is operated earlier than 
$\mathrm{CP}$, the presence of a similar increase in palatal SPP1 in humans during the early neonatal period could explain the higher levels of SPP1 in CLP compared to CP.

In conclusion, by Gene chip analysis and staining with selected antibodies in human embryonic palates, we found supportive evidence that osteopontin (SPP1), chemokine receptor 4 (CXCR4), serglycin (PRG1) and immune related factors may play a role in the development of the normal palate, and perhaps different roles in the development of the cleft palates in CP compared to CLP, although this is uncertain due to age differences in the CP and CLP subgroups. Our data pointed to an interesting cross regulation between immune related factors and bone metabolism, a finding which should be explored further.

A valuable lesson learned from this study is that future expression studies in cleft lip and palate should preferentially use human foetal tissue with a fixed gestational age in order to reduce the potential for the biases discussed here.

\section{Methods}

\section{Patients}

The study was approved by the local scientific ethics committee. Patients with CL, CLP (only the unilateral type) or $\mathrm{CP}$ only of Caucasian origin were included in the study. The patients were examined by the first author (LPJ) and were excluded from the study if other visible malformations than the CL/P were present. Blood tests or ultrasound examinations were not performed. Tissue samples were collected during the primary cleft operation, if the parents had given their informed written consent. The patients were operated by one of three surgeons at the same hospital. According to the surgical protocols the children with $\mathrm{CL}$ and CLP are operated at approximately four months of age and CP at approximately 16 months of age.

To achieve optimal healing and hence cosmetic and functional results, a small piece of mucosa is routinely removed during the operation from the borders of the cleft region (either lip and/or palate tissue depending on the CL/P type). In each of the three CL/P subgroups, samples were obtained from three patients. As six tissue samples were collected from the CLP patients (three lip and three palate tissue samples), the following two types of comparisons were possible in the total of 12 samples: Expression in lip tissue from patients with $C L$ compared to lip tissue from CLP, and expression in palate tissue from CP compared to CLP. The mucosa samples from the lips and palates are primarily composed of non-keratinized epithelium and sub-epithelial stroma.

In embryological terms the lip samples were taken from mucosa developed from the maxillary (lateral) prominence on the cleft side, not from the frontonasal (median) prominence and samples from the palate were taken from the soft palate mucosa at the borders of the cleft. Only one sample from either lip and/or palate tissue depending on the CL/P type was obtained from each patient.

\section{Affymetrix GeneChip analysis}

Total RNA was extracted from the tissue using the mirVana miRNA Isolation Kit (Ambion Inc., Austin, TX). This kit provides high quality total RNA and can be used both to yield total RNA or RNA enriched for small RNAs, such as miRNAs. Initially, we planned to carry out both gene expression and miRNA expression in the tissue, but as we realized that miRNAs are expressed during embryonic development, we declined to perform the miRNA chip analysis. The quality and quantity of the extracted total RNAs were assessed by agarose gel electrophoresis, spectrophotometric ultraviolet (UV) absorbance at 260/280 $\mathrm{nm}$, and Agilent Bioanalyzer analysis (Agilent Technologies, Inc., Santa Clara, CA). Gene expression was performed on Affymetrix GeneChip Human Genome U133A Plus 2.0 Array (Affymetrix, Inc., Santa Clara, CA). Labelling, hybridization, washing and image scanning were performed according to the Affymetrix standard protocol: Two $\mu \mathrm{g}$ of total RNA was used to synthesise doublestranded cDNA with the Superscript Choice system (Invitrogen) using an oligo(dT) primer containing a T7 RNA polymerase promoter (GenSet). The cDNA was used as the template for an in vitro transcription reaction to synthesise biotin-labeled antisense cRNA (IVT labelling Kit, Affymetrix Inc.). After fragmentation at $94^{\circ} \mathrm{C}$ for $35 \mathrm{~min}$ in fragmentation buffer (40 mM Tris, $30 \mathrm{mM}$ magnesium acetate, $10 \mathrm{mM}$ potassium acetate), the labeled cRNA was hybridised for $16 \mathrm{~h}$ to Affymetrix HG-U133 Plus 2.0 arrays (Affymetrix Inc.), that contain 54,613 probe sets. The arrays were washed and stained with phycoerythrinstreptavidin (SAPE) using the Affymetrix Fluidics Station 450 , and the arrays were scanned in the Affymetrix GeneArray 3000 scanner to produce raw data image files.

Normalization of gene expression values and hierachical clustering were performed using dCHIP software (Li and Wong, 2001). Transcripts were identified as being differentially expressed if the comparison of groups yielded a fold change higher than 1.5 (using the $90 \%$ lower confidence interval of the fold change), a difference of means higher than 50 and a $P<.05$ (two-tailed, two-sample unequal variance $t$-test, Welch test).

\section{Validation by quantitative RT-PCR (QPCR)}

QPCR was performed in nine selected genes (based on their molecular functions according to Gene Ontology Consortium (www.geneontology.org)) in two samples from each of the four groups of tissue; lip tissue from $C L$ and CLP and palate tissue from CP and CLP: CDNA was synthesised with superscript II (RNase $\mathrm{H}^{-}$) reverse transcriptase (Invitrogen, Carlsbad, CA) and QPCR analysis was performed in a DNA Engine Opticon 2 (Biorad, Hercules, CA) using LightCycler FastStart DNA master SYBR Greenl kit (Roche, Indianapolis, IN). Primers were purchased from TAG Copenhagen (Copenhagen, DK). All primers are intron-spanning and designed using Oligo6 software (Cascade, CO). The identity of PCR products and primer sequence specificity was confirmed by BLAST 
analysis (NCBI, NIH, http://www.ncbi.nlm.nih.gov/ BLAST/) and melting curve analyses. Gene expression levels were normalised to the expression of $\beta$-2-microglobulin precursor (B2M). Primer sequences (from $5^{\prime}$ to $3^{\prime}$ ) were: $B 2 M$, forward (F)-TGTGCTCGCGCTACTCTCTC, reverse (R)CTGAATGCTCCACTTTTTCAATTCT; BST2, F-GATGGAGTGTCGCAATGTCA, R-GCCCAGCAGCACAATCA; SPEN, F-GTCCTGGCCCATCGGT, R-TTGGCCTGCAGGTAAGTGAT; DIO2, F-AGAGGGACTGCGCTGCGTCT, R- CTGGCAGCTGGCTCGTGAAA; CRYAB, F-GTTGGGAGATGTGATTGAGG, R-GCTTCTCTTCACGGGTGAT; PACN3, F-GGGTGAGGGCACTCTATGAC, R-GCCCTCAGCCTAGACTCGT; EGFL6, F-AGACATTGGCCGATTGAA, R-ATGCCAGAGGTCCTATGATG; SPP1 (human), F-CTAAGAAGTTTCGCAGACCT, R-CTATCAATCACATCGGAATG; Spp1 (mouse), F-TCTGATGAGACCGTCACTGC, R-TCGGAATTTCAGATACCTATCATCT; CXCR4, F-TCCAGTAGCCACCGCATCT, R-TGCCCACAATGCCAGTTAAG; AMPD2, F-CTCAGCTATCACCGGAATC, R-TCTTTACCTTGTGCGAGAAG.

\section{Validation by immunohistochemistry}

A total of seven human embryos (6th to 8th week) and five human fetuses (9th to 11th week) were examined. The human embryos and fetuses, which ranged from 7-60 mm crown-rump length (CRL), were obtained from spontaneous and legal abortions or ectopic pregnancies. Informed consent was obtained. Immediately following the operation, the embryos and fetuses were dissected into appropriate blocks and fixed for 12 to $24 \mathrm{~h}$ at $4^{\circ} \mathrm{C}$ in one of the following fixatives: $10 \%$ neutral buffered formalin, $4 \%$ Formol-Calcium, Lillie's or Bouin's fixatives. The specimens were dehydrated with graded alcohols, cleared in xylene and paraffin embedded. Serial sections, 3-5 $\mu \mathrm{m}$ thick, were cut in transverse, sagittal or horisontal planes and placed on silanized slides. Representative sections of each series were stained with hematoxylin and eosin or with toluidine blue.

The paraffin sections from tissue blocks containing the craniofacial region (including the palatal shelves) were dewaxed, rehydrated and washed in Tris-buffer saline (TBS: $0.05 \mathrm{M}$ Tris, $0.15 \mathrm{M} \mathrm{NaCl}, \mathrm{pH} 7.6$ ) with $0.01 \%$ Nonidet P-40 (TBS/Nonidet)). All sections were incubated in $1.5 \% \quad \mathrm{H}_{2} \mathrm{O}_{2}$ in TBS/Nonidet for $15 \mathrm{~min}$ to block endogenous peroxidase activity, and then in 10\% normal goat serum in TBS/Nonidet for 30 min to block non-specific binding. Sections were incubated overnight at $4^{\circ} \mathrm{C}$ with the primary antibody, diluted in $10 \%$ goat serum. Sections were incubated with (1) human monoclonal anti-CXCR4 lg, diluted 1:1500 (RD systems MAB173), (2) rabbit polyclonal anti-SPP1 lg, diluted 1:600 (Abcam ab33046), and (3) rabbit polyclonal anti-serglycin lg, diluted 1:400 (kindly provided from the laboratory of Dr. Niels Borregaard, (Niemann et al., 2004)).

The primary antibodies were detected using the peroxidase revelation method (DakoCytomation EnVision+ DualLink System), according to the manufacturer's recommendations. As negative controls, sections were incubated with only the secondary antibody.

\section{In silico analysis}

The Craniofacial and Oral Gene Expression Network
(COGENE) is a publicly available database, comprising gene expression profiles (Affymetrix GeneChip analysis and Serial Analysis of Gene Expression (SAGE)) from human embryonic craniofacial structures. Our results in palate tissue were compared to COGENE Affymetrix expression profiles from the following structures, since these structures develop into palatal tissue: 4th week pharyngeal arch 1,5th week pharyngeal arch 1,6th week maxilla, and 8.5th week palatine shelves. Expression in lip tissue was compared to COGENE Affymetrix expression profiles from: 4th week pharyngeal arch 1 , 5th week pharyngeal arch 1, 6th week maxilla, 4th week frontonasal prominence, 5th week frontonasal prominence, 6th week median nasal prominence, and 8.5th week upper lip, as these structures develop into lip tissue. A few COGENE SAGE profiles were relevant for the lip development: 4th week frontonasal prominence, 5th week frontonasal prominence, and 8.5th week upper lip.

Signalling pathways were analyzed using a human protein interaction network, which we have previously constructed using several network databases (Lage et al., 2007).

\section{Acknowledgments}

We thank the patients and their families for participating in the study, and Karen Henriksen and Dorrit Nolting for skilful technical assistance. The work was partly supported by grants from the Augustinus Foundation, the Vanfoere Foundation, Doctor Johan Boserup and Lise Boserups Foundation, Aase and Ejnar Danielsens Foundation and The Research Foundation of the Queen Louise Childrens Hospital. Wilhelm Johannsen Centre for Functional Genome Research was established by the Danish National Research Foundation.

\section{Electronic-database information}

The URLs for data presented herein are as follows: Craniofacial and Oral Gene Expression Network (COGENE), http://hg.wustl.edu/cogene/Gene Ontology (GO), http://www. geneontology.org/Online Mendelian Inheritance in Man (OMIM), http://www.ncbi.nlm.nih.gov/omim/UCSC Genome Bioinformatics site, March 2006 assembly, http://www. genome.ucsc.edu/

\section{References}

Avila JR, Jezewski PA, Vieira AR, Orioli IM, Castilla EE, Christensen K, Daack-Hirsch S, Romitti PA, Murray JC. PVRL1 variants contribute to non-syndromic cleft lip and palate in multiple populations. Am J Med Genet 2006; 140:2562-70

Brown NL, Knott L, Halligan E, Yarram SJ, Mansell JP, Sandy JR. Microarray analysis of murine palatogenesis: temporal expression of genes during normal palate development. Dev Growth Differ 2003;45:153-65

Christensen K, Mitchell LE. Familial recurrence-pattern analysis of nonsyndromic isolated cleft palate - a Danish Registry study. Am J Hum Genet 1996;58:182-90 
Fogh-Andersen P. Inheritance of Harelip and Cleft Palate. Arnold Busck, 1942, Copenhagen

Harville EW, Wilcox AJ, Lie RT, Vindenes H, Abyholm F. Cleft lip and palate versus cleft lip only: are they distinct defects? Am J Epidemiol 2005;162:448-53

Holladay SD, Sharova LV, Punareewattana K, Hrubec TC, Gogal RM Jr, Prater MR, Sharov AA. Maternal immune stimulation in mice decreases fetal malformations caused by teratogens. Int Immunopharmacol 2002;2:325-32

Jono S, Peinado C, Giachelli CM. Phosphorylation of osteopontin is required for inhibition of vascular smooth muscle cell calcification. J Biol Chem 2005;275:20197-203

Jugessur A, Murray JC. Orofacial clefting: recent insights into a complex trait. Curr Opin Genet Dev 2005;15:270-8

Kolset SO, Tveit H. Serglycin--structure and biology. Cell Mol Life Sci 2008;65:1073-85

Lage K, Karlberg EO, Storling ZM, Olason PI, Pedersen AG, Rigina O, Hinsby AM, Tümer Z, Pociot F, Tommerup N, Moreau Y, Brunak S. A human phenome-interactome network of protein complexes implicated in genetic disorders. Nat Biotechnol 2007;25:309-16

Li C, Wong WH. Model-based analysis of oligonucleotide arrays: expression index computation and outlier detection. Proc Natl Acad Sci USA 2001;98:31-6

Metneki J, Puho E, Czeizel AE. Maternal diseases and isolated orofacial clefts in Hungary. Birth Defects Res A Clin Mol Teratol 2005;73:617-23

Mukhopadhyay P, Greene RM, Zacharias W, Weinrich MC, Singh S, Young WW Jr, Pisano MM. Developmental gene expression profiling of mammalian, fetal orofacial tissue. Birth Defects Res A Clin Mol Teratol 2004;70:912-26

Murray JC. Gene/environment causes of cleft lip and/or palate. Clin Genet 2002;61:248-56

Niemann CU, Cowland JB, Klausen P, Askaa J, Calafat J, Borregaard N. Localization of serglycin in human neutrophil granulocytes and their precursors. J Leukoc Biol 2004;76: 406-15

Rittling SR, Matsumoto HN, McKee MD, Nanci A, An XR, Novick KE, Kowalski AJ, Noda M, Denhardt DT. Mice lacking osteopontin show normal development and bone structure but display altered osteoclast formation in vitro. J Bone Miner Res 1998;13:1101-11
Rual JF, Venkatesan K, Hao T, Hirozane-Kishikawa T, Dricot A, Li N, Berriz GF, Gibbons FD, Dreze M, AyiviGuedehoussou N, Klitgord N, Simon C, Boxem M, Milstein S, Rosenberg J, Goldberg DS, Zhang LV, Wong SL, Franklin G, Li S, Albala JS, Lim J, Fraughton C, Llamosas E, Cevik S, Bex C, Lamesch P, Sikorski RS, Vandenhaute J, Zoghbi HY, Smolyar A, Bosak S, Sequerra R, Doucette-Stamm L, Cusick ME, Hill DE, Roth FP, Vidal M. Towards a proteomescale map of the human protein-protein interaction network. Nature 2005;437:1173-8

Sharova LV, Gogal RM Jr, Sharov AA, Chrisman MV, Holladay SD. Immune stimulation in urethane-exposed pregnant mice increases expression level of spleen leukocyte genes for TGFbeta3 GM-CSF and other cytokines that may play a role in reduced chemical-induced birth defects. Int Immunopharmacol 2002;2:1477-89

Suzuki K, Hu D, Bustos T, Zlotogora J, Richieri-Costa A, Helms JA, Spritz RA. Mutations of PVRL1, encoding a cell-cell adhesion molecule/herpesvirus receptor, in cleft lip/palate-ectodermal dysplasia. Nat Genet 2000;25:427-30

Taniguchi T, Takaoka A. The interferon-alpha/beta system in antiviral responses: a multimodal machinery of gene regulation by the IRF family of transcription factors. Curr Opin Immunol 2002;14:111-6

Theocharis AD, Seidel C, Borset M, Dobra K, Baykov V, Labropoulou V, Kanakis I, Dalas E, Karamanos NK, Sundan A, Hjerpe A. Serglycin constitutively secreted by myeloma plasma cells is a potent inhibitor of bone mineralization in vitro. J Biol Chem 2006;281:35116-28

Wahl SM, Vazquez N, Chen W. Regulatory T cells and transcription factors: gatekeepers in allergic inflammation. Curr Opin Immunol 2004;16:768-74

Walsh MC, Kim N, Kadono Y, Rho J, Lee SY, Lorenzo J, Choi Y. Osteoimmunology: interplay between the immune system and bone metabolism. Annu Rev Immunol 2006;24:33-63

Zucchero TM, Cooper ME, Maher BS, Daack-Hirsch S, Nepomuceno B, Ribeiro L, Caprau D, Christensen K, Suzuki Y, Machida J, Natsume N, Yoshiura K, Vieira AR, Orioli IM, Castilla EE, Moreno L, Arcos-Burgos M, Lidral AC, Field LL, Liu YE, Ray A, Goldstein TH, Schultz RE, Shi M, Johnson MK, Kondo S, Schutte BC, Marazita ML, Murray JC. Interferon regulatory factor 6 (IRF6) gene variants and the risk of isolated cleft lip or palate. N Engl J Med 2004;351:769-80 